\author{
Kresimir FASAIC ${ }^{1)}$, Ljubica $D E B E L J A K^{1)}$, Zdenek $A D A M E K^{2)}$
}

Fish culture

\title{
THE EFFECT OF MINERAL FERTILIZATION ON WATER CHEMISTRY OF CARP PONDS
}

\section{WPEYW NAWOZENIA MINERALNEGO NA CHEMIZM WOD STAWÓW KARPIOWYCH}

\author{
1) Fisheries Research Center, Faculty of Agricultural Sciences, \\ University of Agriculture, Zagreb, Yugoslavia \\ 2) Department of Fisheries and Biosphere Protection, Faculty of Agronomy, \\ University of Agriculture, Brno, Czechoslovakia
}

The basic physico-chemical parameters of the water were studied in the experimmtal fish ponds of "Draganici" (Yugoslaviv) during the rearing seasion of the 1985. The particular atetention was taken to the changes of ammounts of dissolved $\mathrm{O}_{2}$ and $\mathrm{NO}_{3}^{-}, \mathrm{NH}_{4}^{+}$, and $\mathrm{PO}_{4}^{3-}$ ions in the water under the conditions of feetilized experimental ponds by the mineral fertilizer NPK. with the formula of 17:8:9.

The concentration of oxgen in fertilized ponds increased in the middle of rearing season by 2 to $129 \%$, while at the and it decreased by about $20 \%$ in comparison with nonfertilized ponds.

The need for phosphates was not ahown in September, but the necessity of nitrates was evident during the whole period under study.

The significant increase occured in ammount of $\mathrm{NH}_{4}^{+}$ after fertilization, but already after the second day the aplication of fertilizers it constantly decreased.

\section{INTRODUCTION}

The fertilization of carp ponds can be considered as an important way of the intensification of fish culture. The obtained increase of natural fish food resources results in better growth and physiological condition of fish reared 
(Guziur, Adamek, in press). The need of nitrogen and phosphorus fertilization on carp ponds was confirmed by long-term obsaervations of many authors in Yugoslavia (Plančić, Ristić 1961 , Pujin 1966, Bralić et al. 1967, Bralić. 1969, 1971, Debeljak 1968, 1970, 1973, 1978, 1981, Livojecic 19070, Rzanicanin, Balzer 1976, Debeljak et al. 1979, Fašaić et al. 1984). But in was found in any occasions that the fertilization using the inorganic nitrigen and phosphorus did not bring the positiv action (Fijan et al. 1964, Fijan 1966, Pujin et al. 1973), Manily in Czechoslovakia where the content of these chemical elements is extremely high in surface waters (e. g. Janecek et al. 1966, Herzog, Heteša 1968, Losos 1969). In these conditions the need of organic fertilizing using the wastes from animal husbandry and/or food industry seems to be much more topical way to keep the adequate conditions for successfull rearing of cyprinids (Adamek et al. 1987, in press, Brož. Nevrkla, in press).

Besides the effect on pond productivity especially hydrochemical remige and zoohygienic conditions are directly influenced by inorganic compounds. Many literature data confirm this facts. The influence of fertilization on chemical parameters of the water in carp ponds was studied relatively rarely in Yugoslavia (Asaj et al. 1962, Debeljak, Turk 1981, Fašaić et al. 1984, Debeljak, Fašaic 1985, Fašaic 1985), although this problem is well known for a long time, esp. in the connection with hogh fish stock density per surface unit and intensive feeding of fish by artificial feeds.

The aim of our studies was to determine the doses and terms of fertilization resulting in increasing productivitx and keeping fo good zoohygienic conditions of treated ponds. The correct application of fertilizers can be considered as a very profylactic interference as well.

\section{MATHERIAL AND METHODS}

The observations were performed in fish farm "Draganici" during the rearing season of the year 1985 , and five variants in nine experimental ponds (the acreage $1000 \mathrm{~m}^{2}$ ) were used.

The variant II (ponds 4 and 5) was used as the control without fertilizing and the variants III (ponds 2 and 3), III (pond 7), IV (ponds 9 and 10), and $\mathbb{V}$ (ponds 12 and 13) were fertilized by mineral fertilizer NPK. (formula $17: 8: 9$ ). Fertilizing was applied in six doses using 100 and/ or $150 \mathrm{~kg} \cdot \mathrm{ha}^{-1}$ during the rearing season (23.05. to 09.09.1985). Totally, $800 \mathrm{~kg}$ per ha of fertilizer were used.

The one-year-old fish (carp, bighead carp, silver carp, and grass carp) in stocking rates of $3000 \mathrm{ind}^{-h^{-1}}$ (variant II and III), $3200 \mathrm{ind}^{-\mathrm{ha}^{-1}}$ (variant III), 3400 ind. $\mathrm{ha}^{-1}$ (variant $\mathrm{V}$ ) were stocked into the experimental ponds. The losses of fish in individual variants were as follows: $\mathbb{I}-18.5 \%, \mathbb{I}-20.7 \%$, III - $18.5 \%$, IV $25.0 \%$, and $V-17.3 \%$. 
The experimental ponds were treated by calcium hydrate in the dose of $2000 \mathrm{~kg} \cdot \mathrm{ha}^{-1}$ before stockingof fish.

Chemical analysis os water were performed before fertilizing and from the first to the seventh day after that. Following chemical parameters were measured in the water: oxygen, carbon dioxide. $\mathrm{pH}, \mathrm{Ca}^{2+}, \mathrm{Mg}^{2+}$, nitrates, ammonium, phosphates, and $\mathrm{COD}\left(\mathrm{KMnO}_{4}\right)$ values. Water analysis were performed by "Methods of physico-chemical) anallyses of water" (1966), these colorimetric ones using electric colorimeter, and pH-meter "Iskra".

\section{RESULTS}

During the breeding season, about 40 , and $80-90 \%$ of the surface of experimental ponds $(5,7,9,10$, and $2,3,4,12$ and 13 , resp.) were overgrown by macrophytes. Trapa natans, Ceratophyllum demersum, Ranunculus sp., Myriophyllum sp., Potamogeton pectinatus and Potomogeton natans dominated in these plant communities.

Table 1

The average water temperature in individual months of rearing season

\begin{tabular}{|l|llllll|}
\hline Month & May & June & July & Aug. & Sept. & Oct. \\
\hline Temparature $\left({ }^{\circ} \mathrm{C}\right)$ & 21.4 & 21.0 & 23.8 & 23.1 & 19.7 & 18.8 \\
\hline
\end{tabular}

Table 2

The average values of analysed parameters in individual variations of experimental ponds $(\overline{\mathrm{x}} \pm \mathbb{S} \overline{\mathrm{x}})$

\begin{tabular}{|c|c|c|c|c|c|}
\hline Parameter & $\mathbb{I}$ & III & III & $\mathbb{I V}$ & V \\
\hline $\mathrm{O}_{2}\left(\mathrm{mg} \cdot \mathrm{l}^{-1}\right)$ & $6.52 \pm 0.69$ & $4.98 \pm 0.56$ & $6.07 \pm 0.39$ & $7.19 \pm 0.64$ & $6.74 \pm 0.63$ \\
\hline $\mathrm{O}_{2}$ saturation $(\%)$ & $73.91 \pm 7.44$ & $57.45 \pm 6.66$ & $69.18 \pm 5.00$ & $82.36 \pm 7.46$ & $77.45 \pm 7.62$ \\
\hline $\mathrm{CO}_{2}\left(\mathrm{mg} .^{-1}\right)$ & $2.99 \pm 0.47$ & $4.51 \pm 0.51$ & $6.84 \pm 1.81$ & $3.57 \pm 0.35$ & $4.10 \pm 0.35$ \\
\hline C.O.D.-Mn (mg.1 $\left.1^{-1}\right)$ & $19.11 \pm 1.67$ & $19.42 \pm 1.22$ & $63.37 \pm 3.42$ & $25.70 \pm 1.74$ & $23.59 \pm 1.19$ \\
\hline $\mathrm{Ca}^{2+}\left(\mathrm{mg} .1^{-1}\right)$ & $60.01 \pm 5.12$ & $55.29 \pm 1.78$ & $55.64 \pm 4.23$ & $52.96 \pm 2.38$ & $52.33 \pm 1.88$ \\
\hline $\mathrm{Mg}^{2+}\left(\mathrm{mg} \mathrm{l}^{-1}\right)$ & $25.81 \pm 2.46$ & $23.57 \pm 2.24$ & $28.31 \pm 5.13$ & $26.95 \pm 2.54$ & $27.76 \pm 2.77$ \\
\hline $\mathrm{NO}_{3}^{-}\left(\mathrm{mg} .1^{-1}\right)^{\prime}$ & $0.24 \pm 0.03$ & $0.33 \pm 0.05$ & $0.36 \pm 0.06$ & $0.27 \pm 0.03$ & $0.47 \pm 0.06$ \\
\hline $\mathrm{NH}_{4}^{+}\left(\mathrm{mgll}^{-1}\right)$ & $0.46 \pm 0.02$ & $0.41 \pm 0.05$ & $1.25 \pm 0.15$ & $0.78 \pm 0.07$ & $0.66 \pm 0.06$ \\
\hline $\mathrm{PO}_{4}^{3-}\left(\mathrm{mg} \cdot 1^{-1}\right)$ & $0.18 \pm 0.01$ & $0.19 \pm 0.02$ & $0.49 \pm 0.06$ & $0.25 \pm 0.01$ & $0.24 \pm 0.02$ \\
\hline $\mathrm{pH}$ & $7.97 \pm 0.05$ & $7.80 \pm 0.03$ & $7.85 \pm 0.10$ & $8.07 \pm 0.02$ & $8.01 \pm 0.02$ \\
\hline
\end{tabular}

Currently registered water temperature varied from 15 to $27^{\circ} \mathrm{C}$. The observations of temperature during the breeding season are given in Table I snd Fig. 1 , and the average values of individual hydrochenaical parameters are given in Table 2. 


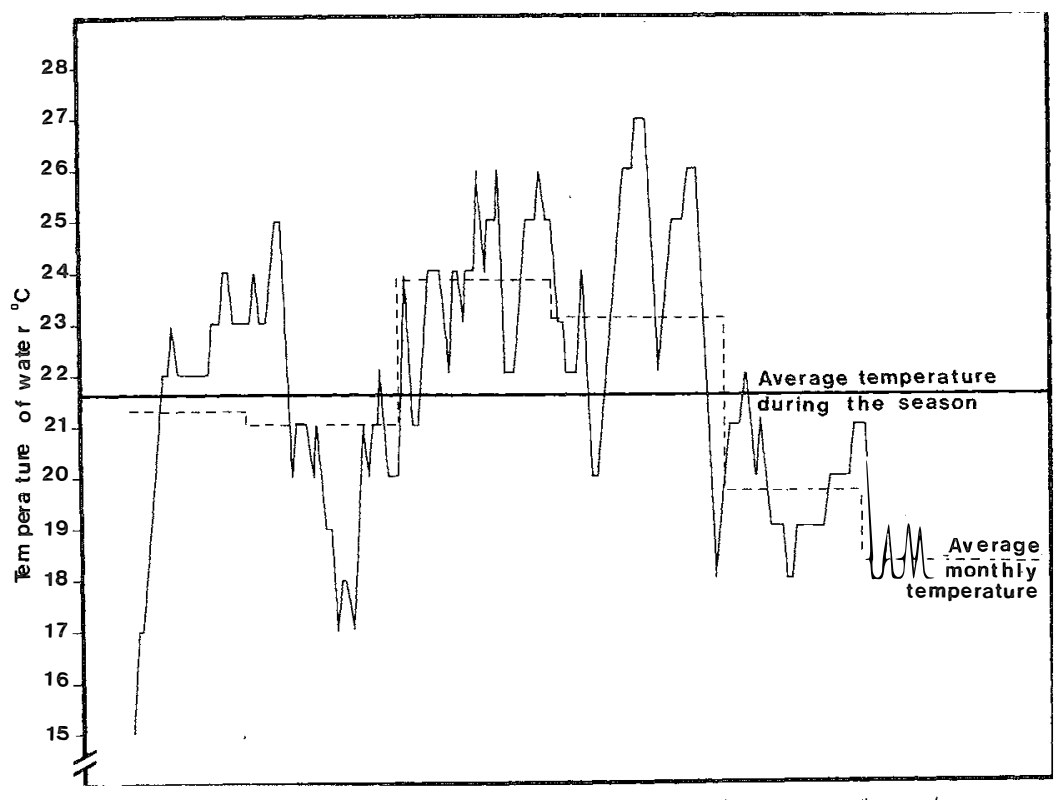

5.

6.

7.

8.

9.

10. MONTH

Fig. 1. Daily dynamics of water temperature during the rearing season

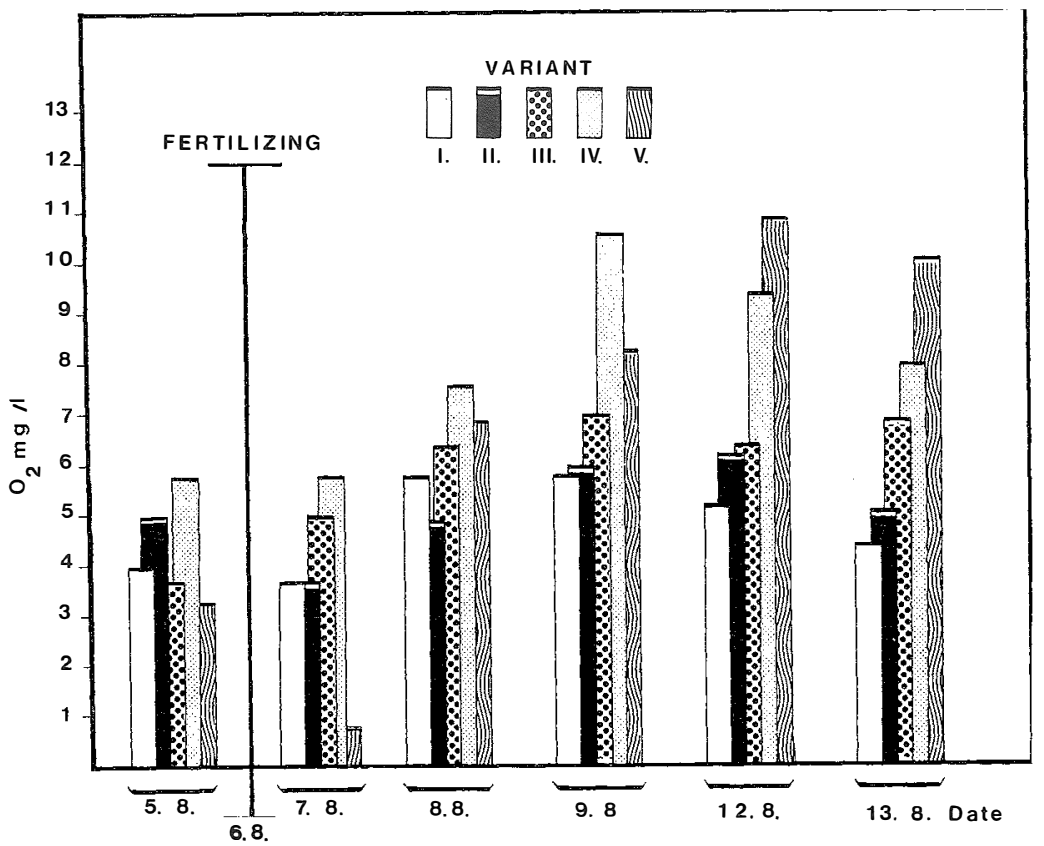

Fig. 2. The average oxygen content in the water of different experimental pond variants before and after fertilizing on Aug. $6^{\text {th }}$, 1985 


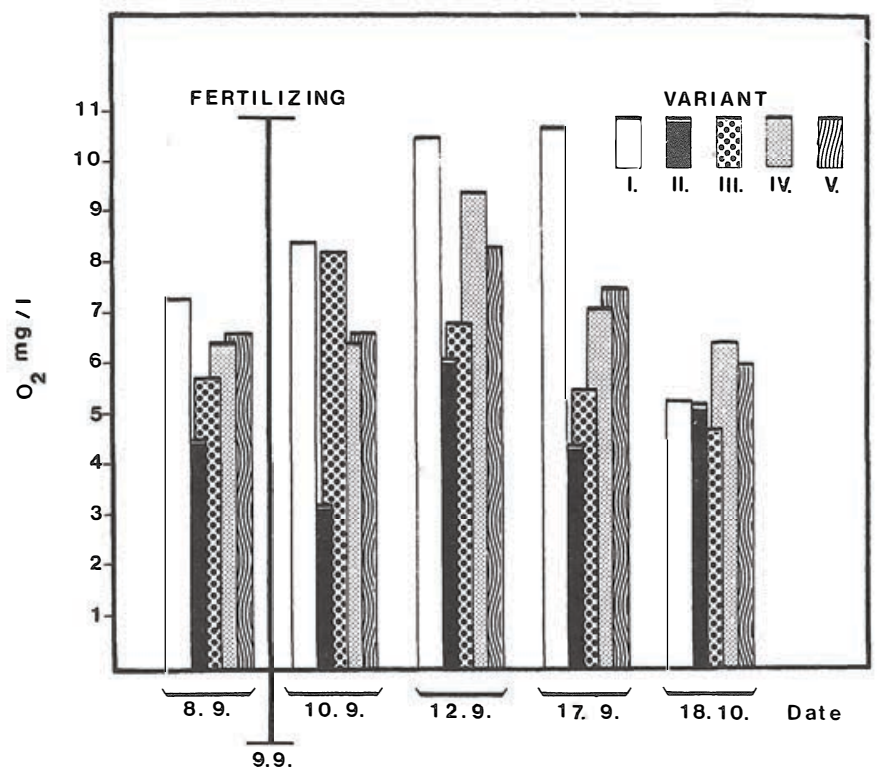

Fig. 3. The average oxygen content in the water of different experimental pond variations before and after fertilizing on Sept. $9^{\text {th }}, 1985$

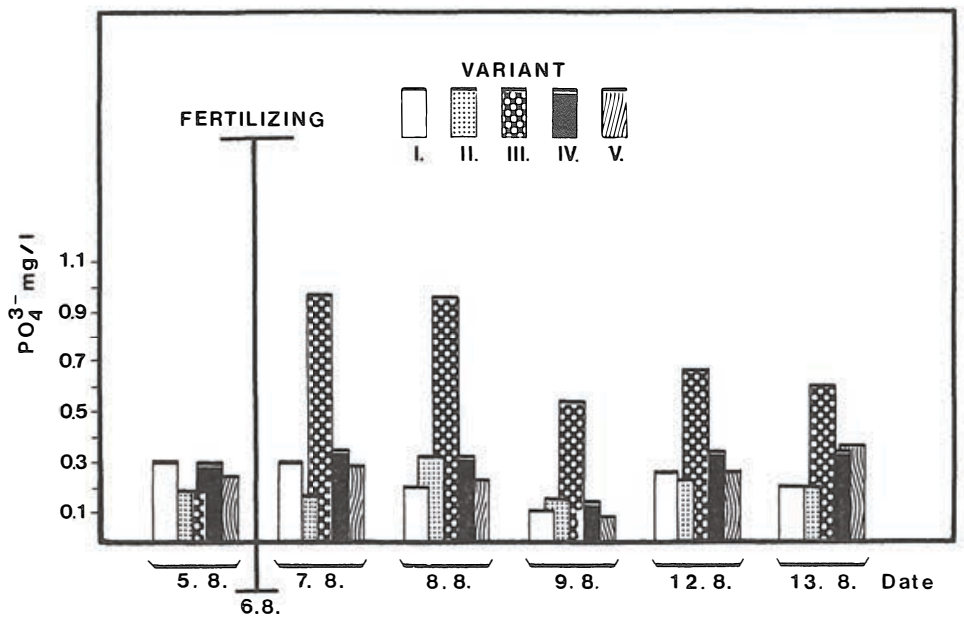

Fig. 4. The average phosphates content in the water of different experimental pond variants before and after fertilizing on Aug. $6^{\text {th }}$, 1985

Evident fluctuations of oxygen concentration in the water of experimental ponds were confirmed during the period of observations. In the morning (measured at about $7 \mathrm{a} . \mathrm{m}$.), the oxygen content varied from 0.64 to $14.4 \mathrm{mg} . \mathrm{l}^{-1}$. The lover differences in oxygen content were registered during August (min. 
$0.64 \mathrm{mg} . \mathrm{l}^{-1}$, max. $\left.12.32 \mathrm{mg} . \mathrm{l}^{-1}\right)$, the values measured during September were much higher min. $2.2 \mathrm{mg.1}{ }^{-1}$, $\max .14 .4 \mathrm{mg} . \mathrm{l}^{-1}$ ). The dynamics of oxygen dissolved in the water during the period of observations is given in Fig. 2 and 3.

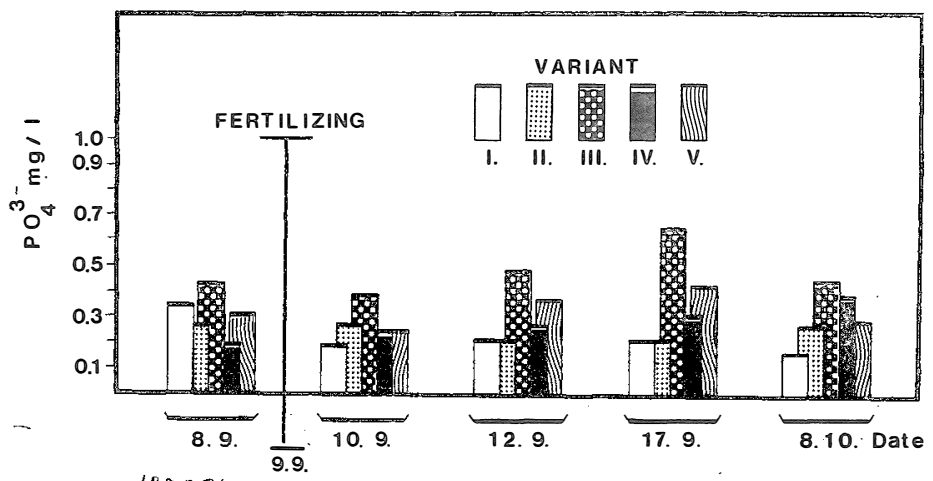

Fig. 5. The average phosphates content in the water of different experimental pond variations before and after fertilizing on Sept. $9^{\text {th }}, 1985$

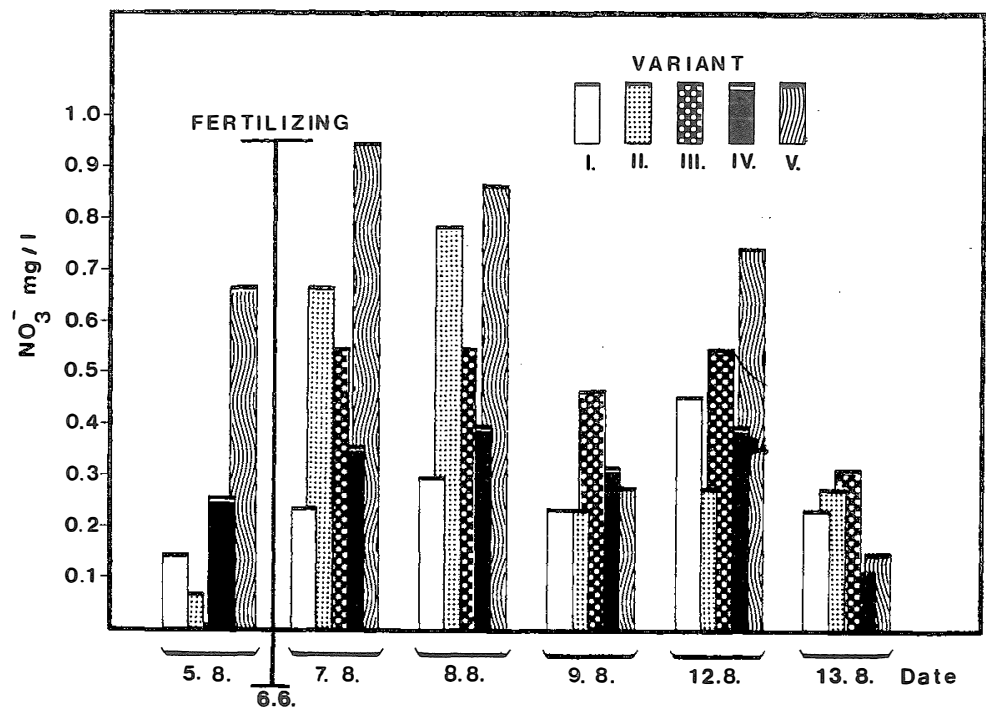

Fig. 6. The average nitrates content in the water of different experimental pond variants before and after fertilizing on Aug. 6 $6^{\text {th }}, 1985$

The dynamics of phosphates, mitrates and ammonium was registered immediately after the application of fertilizers. The results obtained are documented in Fig. 4-9. The highest content of phosphates in the water was registered in pond 3 in August from the first to the first to the seventh day after fertilization. Sudden raise of phosphate content immediately after fertilization persisted there for seven days, followed by the slow decrease. 
The increase of phosphates in the water alleady the second day after fertillization was registered in remaining ponds, but in the third day its concentration decreased. It testifies its rapid consumtion by phytoplankton and macrophytes in these experimental ponds.

During September, the phosphate concentration increased just the first day after fertilization and stood on the favourable values untill the eighth day sfter this treatment. Its increase occured until the first half of October, one month after fertilizing. The level of phosphates in fertillized ponds was very favourable and higher than in non-fertilized ponds. The utilization of phosphates in September was lower in comparison with its consumption in August.

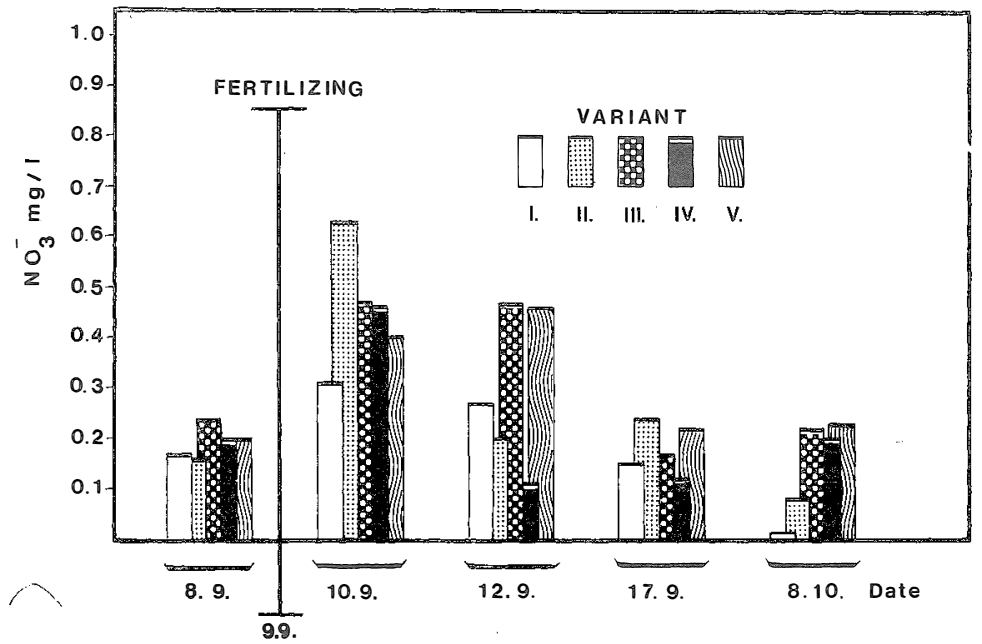

Fig. 7. The average nitrates content in the water of different experimental pond variants before and after fertilizing on Sept. $9^{\text {th }}, 1985$

Similar results were obtained in dynamics of ammonium and nitrate jons. The nitrate concentration increased in both terms just the first day after applications of fertilizer and stood on this level only until the second day. Then, the continuous and irregular decrease of nitrate concentration was observed from the third to seventh day after fertilization. The following conclusion can be made from this fact, that the need of nitrates was higher in experimental ponds (differently from phosphates) during the period of observations.

A special inerest should be taken to the results of the observations of ammonium nitrogen dynamics. During the experiments, the evident increase of ammonium ions occured in fertilized ponds just the first day after treatment. Increased concentrations of ammonium ions in the water were registered until the second day after fertilization. The continuous decrease of their content followed later untill the seventh day after the treatment except of the ponds in variant II where already the third day after fertilization the ammonium content evidently dropped. 


\section{DISCUSSION}

The water chemistry analyses confirmed the seasonal fluctuations of invidual parameters in experimental ponds, and this fact is considered as a characteristic phenomenon of carp ponds. The comparison of the average values of individual chemical parameters cinfirmed the differences in contents of $\mathrm{NO}_{3}^{-}, \mathrm{NH}_{4}^{-}$, and $\mathrm{PO}_{4}^{3-}$ ions in the water of some fertilized variants compared with non-fertilized ponds especially in following facts: $\mathrm{NO}_{3}^{-}$ion content increased in variant II by $38 \%$, in variant III by $50 \%$, in variant IV by $13 \%$, and in variant $\mathrm{V}$ by $96 \%$. $\mathrm{NH}_{4}^{+}$ion content in variants II - V increased in comoarison with non-fertilized variant $\mathbb{I}$ by $0,172,70$ and $43 \%$, resp. and $\mathrm{PO}_{4}^{3-}$ ion content by $6,162,39$ and $33 \%$, resp.

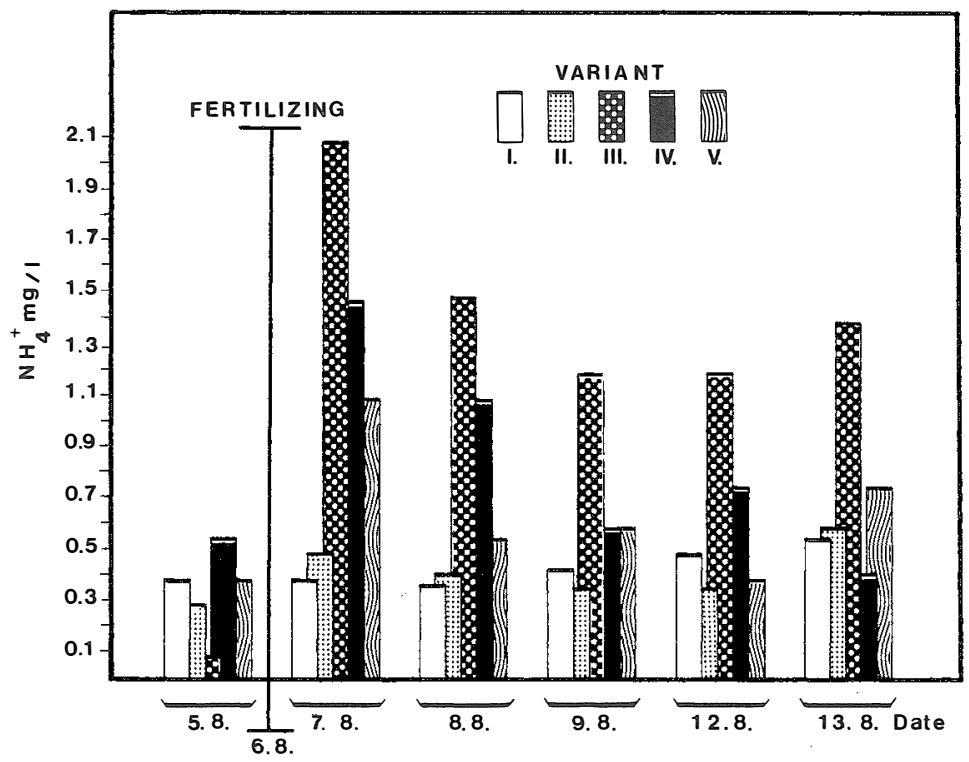

Fig. 8 . The average ammonium content in the water of different experimental pond variants before and after fertilizing on Aug. $6^{\text {th }}, 1985$

In August, the irregular average values of oxygen concentration were registered before fertilizing and two days after that. From the third to seventh day after the application of fertilizers, the oxygen content in the water ot the fertilized ponds was by 2 to $129 \%$ higher as compared with non-fertilized control variant.

The different curve of oxygen content dynamics in the water was registered during September and at the beginingg of November. In non-fertilized varian its content varried in average from 5.44 to $10.64 \mathrm{mg} . \mathrm{l}^{-1}$, while in fertilized ponds fluctuated these values from 3.28 to $9.52 \mathrm{mg} . \mathrm{l}^{-1}$. Higher content of 
oxygen in the water of non-fertilized ponds was registered especially in September.

This dynamics of oxygen in the water can be explained by different development of photoplankton communities and different water temperature. In August, when the water temperature was always higher than $20^{\circ} \mathrm{C}$, the rapid development of phytoplankton was observed three days after fertilizing. Due to the photosyntetic activitz of phytoplankton, the oxygen content in the water was enhanced. The dropping of water temperature under $20^{\circ} \mathrm{C}$ in September lead to the lower development of phytoplankton and resulted in the lower abudance so that fertilizers could not influence its production so effectively in this time. Vinberg's (1958) results confirm this assumption.

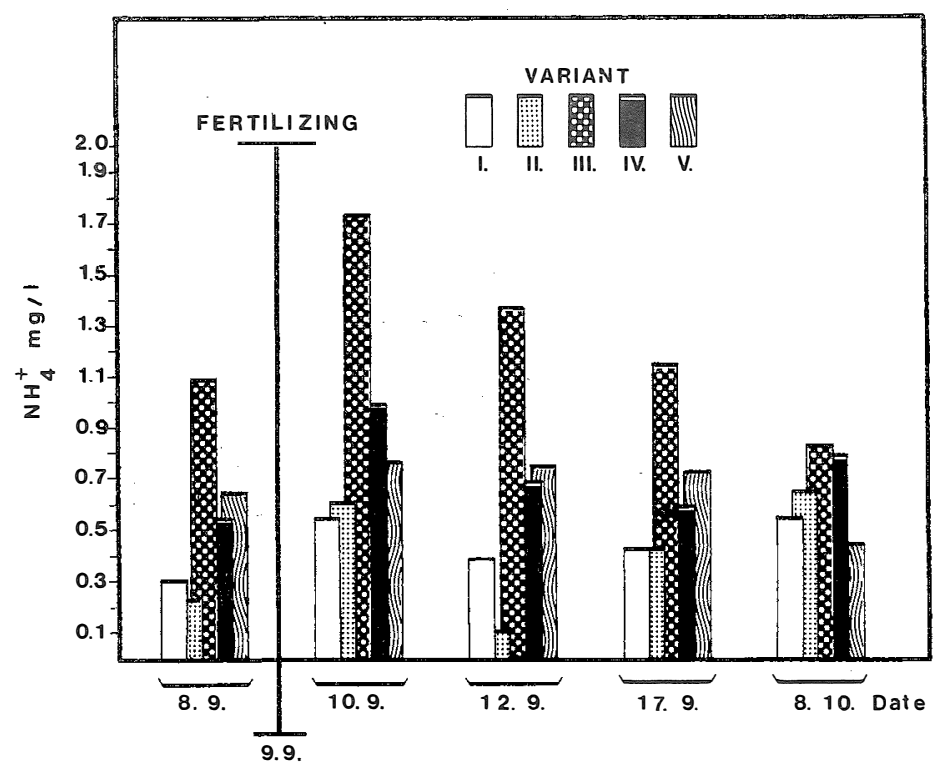

Fig. 9. The average ammonium content in the water of different experimental pond variants before and after fertilizing on Sept. 9ti, 1985

The differences between the ammonium nitrogen dynamics in variant II and remaining experimantal pond were registered during the observations. It is difficult to explain this fact, because in September this concentration increased again. The highest content of $\mathrm{NH}_{4}^{+}$ion was registered in the pond of variant III where the average concentration over $1 \mathrm{mg}_{9} 1^{-1}$ persisted during the whole period under study until the seventh day after fertilization. The increase of ammonium ions was lower in remaining ponds, where after the maximum values in the first day the irregular dropping was registered until the seventh day after fertilizing. The dynamics of ammonium nitrogen after fertilizing 
shows the need of very corefull application of fertilizers containing the nitrogen in the form of ammonium.

The ammount of fertilizer NPK of formulation $17: 8: 9$ in both doses exsceeded 100 and $150 \mathrm{~kg} \cdot \mathrm{ha}^{-1}$, what is about 17 and $25 \mathrm{~kg} \cdot \mathrm{ha} \mathrm{a}^{-1}$ of pure nitrogen in ammonium and nitrate from, resp. This ammount lead to rapid increased of anmoniun ion in pond water. Due to the increased content of $\mathrm{NH}_{4}^{+}$ion in the water and hogh $\mathrm{pH}$ values, the anmount of fertilizer containing nitrogen in ammonium from must be controlled and the application must be practised so that not to allow the increase of non-ionized from of anmonim to the values inducing the harmanll effect on fish.

\section{SUMMARY}

The applied inorganic fertilizer NPK of the formula $17: 8: 9$ in total ammount $800 \mathrm{~kg} \cdot \mathrm{ha}^{-1}$ in six doses (100 and $150 \mathrm{~kg}^{-h_{2}}{ }^{-1}$ ) did not deteriorate zoolhygienic conditions in experinental ponds during the breeding season of the year 1985 .

The oxygen dymanics in the water of fertilized ponds was irregular during the experimental period. Its values increased in the noiddle of culturing season by $2-129 \%$ and decreased at the end of the experiments by $20 \%$ in comparison with non-fertilized ponds.

The amount of $\mathrm{PO}_{4}^{3-}$ ions oncreased after fertilization. Higher consumption of phosphates was observed in summer. Its need was not shown in September.

The dynamics of $\mathrm{NO}_{3}^{-}$ion untill 8 days after fertilization confirmed its need in experimental ponds during the whole period under study.

Rapid increase of $\mathrm{NH}_{4}^{+}$ion was registered in the fertilized ponds inmediately after application of fertilizer, followed by the continuous decrease from the second to the eighth day after fertilization.

\section{REFERENCES}

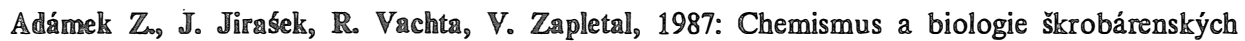
akumulačnich rybniku. [Chemistry and biology of ponds receiving the potato starch industry wastes]. Intenzifikace rybárské vyroby a kvalita vody, Velké Meziřiči: 62-66. (in Czech)

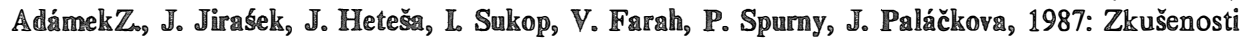
s odchovem plủdku lina a býložravých ryb v monokulturách na OZ SR Pohořelice. [The experiences with rearing of tench and herbivorous fish fry in monocultures and polycultures on State Fishery Pohořelice]. Modemi technologie chovu pludku teplemilných ryb, Pohořelice: 126-134. (in Czech).

Asaj Ao, N. Fijam, J. Malmar, 1962: Neki podaci o koločini dusika, fosfora i kalcija u vodi rezličite 
gnojenilh ribojaka. [Some informations about nitrogen, phosphorus and calcium concentrations in the water of differently fertilized ponds]. Vet arhiv, 32: 83 - 91. (in Serbo-Croatian)

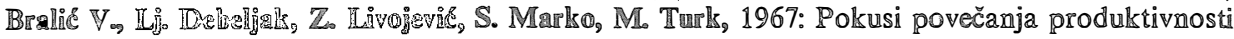
ribnjaka uvodenjem dusičnih mineralnilh gojiva. [Experimental increase of pond productivity by the application of nitrogen inorganic fertilizer], Rib. Jug., 2: 42 - 46. (in Serbo-Croatian)

Bralie $V_{*}$ 1969: Dinamika zooplanktona u ribjacima gnojenim sa umjetrih gnojivima. [Dynamics of zooplasirtozin in ponds fertilized by artificial fertilizers]. Rib. Jug., 24: 99-100 (in Serbo-Croatian)

Bralic $V_{\circ}$, 1971: Rezultati dalmjih istrazivanja o utjecaju kombiniranih mineralnih gaojiva na produlktivaost polkusnilh ribnjaka "Draganiči". [Results of further observations about the influence of combined inorganic fertilizers on productivity of experimental ponds "Draganiči"]. Rib. Jug., 26: 21 - 24. (in Serbo-Croatian)

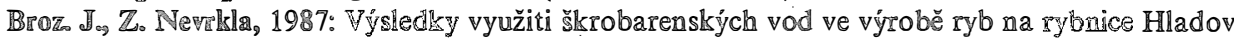
$O Z$ Telc. rigesults of the application of potato starch industry wastes on the fisth-pond

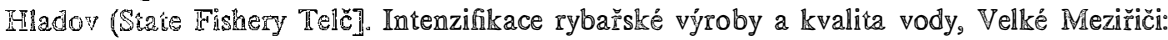
67-73. (im Czech)

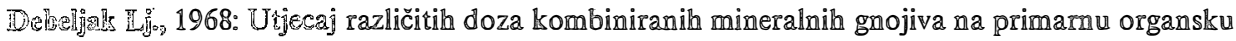
produtrejiju u pokusnim ribnjacima "Draganiči". [The influence of different doses of combined inorganic fertilizers on primary organic production in experimental ponds

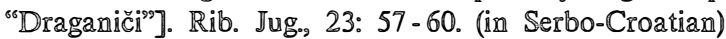

Debeliak Ljo, 1970: Djelovanje mineralnih gaojiva na sezonske promjene fitoplankiona u pokusnim ribnjacima "Draganiči". [The effect of inorganic fertilizers on seasonal changes of phytoplankton in experimental ponds "Draganiči"]. Rib. Jug., 25: 122-125. (in Serbo-Croatian)

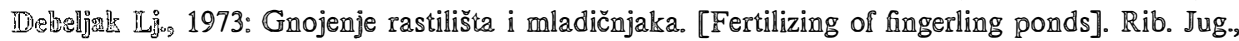
28: 99-101. (in Serbo-Croatian)

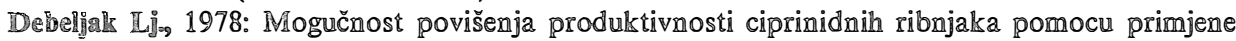
mineralnih gnojiva. [The possibility of increasing of productivity in carps ponds using inorganic fertilizers]. Savjetovanje INA-Petrokemija u poljoprivredi, Oparija; 278 - 290. (in Serbo-Croatian)

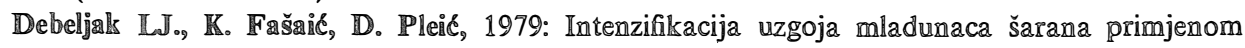
mineralnih i organskilh gnojiva. [Intensification of carp fry rearing using inorganic and fertilizers], Rib. Jug., 34: 77 - 82. (in Serbo-Croatian)

DebeljøkLjo, 1981: Intenzifikacija uzgoja šaranskog milada u proizvodnim uvjetıma. Lintensification of carp fry rearing in practise]. Rib. Jug., 36: $127-130$. (in Serbo-Croatian)

Debeljals $\mathbb{L}_{j o}, \mathbb{J}$. Geyer, $\mathbb{Z}$. Bebels, 1980: Uzgoj šaranskih mladunaca u proizvodnim uvjetima. [Carp fry rearing in practise]. Rib. Jug, 35: 130-136. (in Serbo-Croatian)

Debeljøks Ljo, M. Turk, 1982: Gusteća nasada kao faktor povećanja proizvodnje riba u šaranskim ribnjacima. [Increased stock density as a factor of fish production in carp ponds]. Rib. Jug., 36: 25-29. (in Serbo-Croatian)

Debeljak $\mathbb{L j}_{\text {jo, }} \mathbb{K}$. Fašaic 1985: Hidrokemijski režim mladičnjaka u uvjetima organsko mineralne gnojidbe. [Hydrochemical regine of the fingerling pond after organic and mineral fertilization]. Ekologija, 20: 37-46. (in Serbo-Croatian)

Fašaic $\mathbb{K}_{\text {e, }} \mathbb{L}_{j}$ 。 Debeljaks, $\mathbb{D}$. Chavrak, 1984: Hydrokemijski režim šaranskih ribnjaka u uvjetima inteazivne gnojidbe. [Hydrochemical regime of carp ponds treated by intensive fertilization]. Bilten Društva ekologa $\mathbb{B i H}, \mathbb{B} 2: 165-169$. (in Serbo-Croatian)

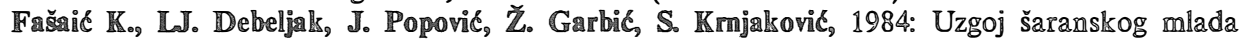
u uvjetima gnojidbe. [Carp fry rearing using the intensive fertilization]. Ichtyologia, 16: 85-101. (in Serbo-Croatian)

Fæšæi̊ $\mathbb{K}_{\infty}$, 1985: Hidrokemijski režim šaranskih ribnjaka u prvoj godni proizvodnje. [Hydrochemical regime of carp ponds in the disrst year of expoatation]. Ekologija, 20: 75-85. (in Serbo-Croatian) 


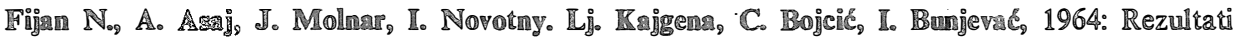
trogodišmilh polusa o gnojenju šaranskilla ribmjaka u prakričnino uslovina. [Results of thee-year experinents with carp ponds fertilizing in practise]. Rib. Jug., 19: 123-139. (in Serbo-Croatian)

Fijam $\mathbb{N}_{\infty}$ 1966: Problems in carp tish pond fertilization. FAO World Symposimn on Warm-water Pond Fish Culture, Rome.

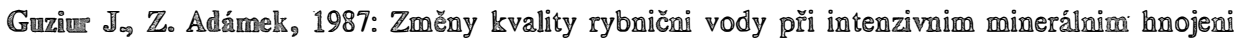
NPR. [Changes of pond water quality in conditions of intensive NPR fertilizing]. Intenzifikace rybařske vyrroby a kvalita vody, Vellsé Maziñici: 100-107. (1ia Czech)

Herzog Ro, J. Hetesa, 1968: Primárni produkce plankronu jako ulkazatel účinnosti lanojeni rybaìû. [Primary production of plankron as an inder of the effectivity of pond fertilization]. Práce VƯRH Vodnany, 8: 5-25. (in Czech)

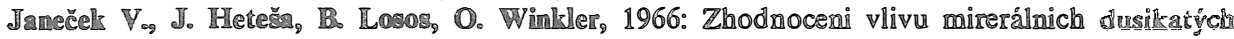
2 fosforečných hnojiv na chemismus, biologii a produlsci esperinentálnich parcelových rybnickur. [Evaluation of the influence of mineral nitrogenous and phosphoric fertilizers on chemism,bilogy and production of experimental parcel fish-ponds]. Práce VŨRI Vodüany. 6: 5-40. (in Czech)

Livojevie $\mathbb{Z}_{\infty}$ 1970: Mogučmosí povišenja prinosa šarana i prateče ribe na $2000 \mathrm{~kg} / \mathrm{ha}$. [The possibility of increasing of the increment of carp and supplemental fish to 2000kg/ha]. Rib. Iug., 25: 42-45. (in Serbo-Croatian)

Losos $\mathbb{B}_{0}$ 1969: Naturliche Ernährung und Waclasturo der Karpenbrut (Cypronus carpio $\left.\mathbb{L}.\right)$ unter Bedingungen der Teiche. Foll. Fac. Sci. Nat. Univ. Purls. Brun, Biologia, 25: 55-66.

Metode za fizičko i kemoijsko ispitivanje voda, 1966. [Mezloods of physico-chenoical anallyses of water. Službeni list SFRJ, 42: 854-866. (in Serbo-Croatian)

Plančic Jo, O. Ristič, 1961: Dubrenje ribajaka. [Pond fertilizing]. Rib. Jug., 16: 18 - 21. (in Serbo- Croarian)

Pujin $V_{\text {o, }}$ 1966: La retilisation et son influence sur l'augementation de la production passagere êt finale dans certaine etangs de Vojvodina FAO World Symposinn on Warm-Water Pond Culiure, Rome.

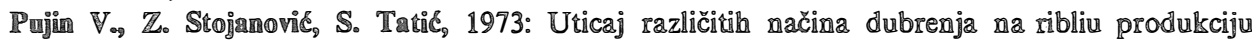
u elssperinentalnim uslovina. [Influence of different ways of fertilization on fish production in experimental conditions]. Ichthologia, 5: 135-142. (in Serbo-Croatian)

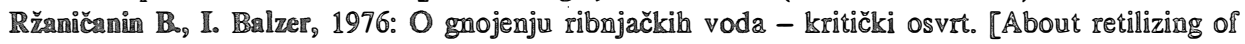
pound water - critical remarks]. Rib. Jug., 31: 121-125. (in Serbo-Croatian)

Vimberg $\mathbb{G}_{0} \mathbb{G}_{0}$ 1958: Issledovanija po effelstivnosti nimeralnych udobrenij na opytnych prudach prudchoza, „Šenetovo". Soobšč. I. Obščij očerls issledovanija na opytrnych prudach prudchoza "Srometovo" i gidrochimičeskije ossobennosti ich. [The observations of mineral fertilizing effectivity in experimental ponds of pond fishery „Shmetovo". Part I. General description of observations in experimental ponds of pond fishery "Shmetovo" and their hydrochemical pecularities]. Gidrobiologičeskije issledovanija na rybovodnych prudach $\mathbb{S S S R}$, Minsls: 79-93. (in Russian) 
Kresimir Fašáic, Ljubica Debeljak, ZZdenek Adámek

\section{WPLYW NAWOŻENIA MINERALNEGO NA CHEMIZM WÓD STAWÓW KARPIOWYCH}

\section{STRESZCZENIE}

Nawóz mineralny NPK (o składzie 17:8:9), zastosowany w 6 dawkach po 100 lub $150 \mathrm{~kg} / \mathrm{ha}$ (ogólem $800 \mathrm{~kg} / \mathrm{ha}$ ) nie pogorszył warunków zoohigienicznych w stawach doświadczalnych, w sezonie hodowlanym 1985 roku.

Stwierdzono różnice w zawartości tlenu. w wodzie nawożonych stawów, w trakcie przeprowadzanego doświadczenia. W polowie sezonu hodowlanego zawartość tlenu w wodzie wzrosła - 2 do $12 \%$, pod koniec eksperymentu zaś, zmalała o $20 \%$ w porównaniu do stawów nie nawożonych.

Ilość jonów fosforanowych wzrosła po nawożeniu. Wyższy pobór fosforanów obserowano w sezonie letnim, przy braku zapotrzebowania na nie we wrześniu.

Zmiany zawartości jonów azotanowych w wodzie, obserowano do 8 dnia po nawożeniu, potwierdziły zapotrzebowanie na nie w trakcie calego okresu hodowlanego. W przypadku jonów amonowych, odnotowano raptowny wzrost ich ilości bezpośrednio po zastosowaniu nawozu, po którym notowano stały spąek ich ilości między drugim a ósmym dniem po nawożeniu.

Author's address:

Received: 1989.06 .23

Dr. Zdenek Adámek

Department of Fisheries

University of Agriculture

Zemedelska 1

61300 BRNO

Czechoslovakia 